\title{
Stock Market and Economic Growth in Nigeria
}

\section{Popoola Olabisi R., Ejemeyovwi O. Jeremiah, Alege O. Philip (Ph.D), Adu Omobola, Onabote A. Ademola}

Department of Economics and Development Studies, College of Development Studies, Covenant University, Ota, Ogun State, Nigeria

\begin{abstract}
This study investigates the short run effect, long run effect and causal relationship between stock market and economic growth in Nigeria. The Augmented Dickey Fuller unit root test, Ordinary Least Squares, Johansen Cointegration test and Pairwise granger causality methods were applied to the variables. The OLS result showed that the all share index had a significant but negative relationship with economic growth; The Johansen cointegration test showed that a long run relationship exists between the stock market performance and economic growth in Nigeria in the long run while the Granger causality test results showed that stock market performance does not granger cause economic growth but economic growth granger causes stock market performance at 5 percent significance level. The study suggested some of the possible reasons for the negative impact of stock market on the Nigerian economic growth and recommended that efforts should be made to improve the stock market performance to have a positive effect on the real gross domestic product of Nigeria overtime.
\end{abstract}

Keywords-All Share Index, Market Capitalization, Stock Market Gross Capital Formation.

\section{ACKNOWLEDGEMENTS}

This paper draws from the second author's undergraduate research project. Thus, suggestions and comments from research committee and faculty in the Department are acknowledged.

\section{INTRODUCTION}

The two markets that determine to a large extent the directions and level of economic growth within an economy, apart from other factors such as political, social and environmental factors, are the money and capital markets (Ahmed, 1998). The financial system in an economy plays a crucial role in the growth and development of an economy. It is used to measure the sophistication of the investment 'climate' of a country especially in attracting foreign investors. The stock market is a medium through which funds can be mobilized and channeled efficiently. It enables the government and industries to finance new and existing projects, expanding and modernizing industrial commercial concern. Okereke (2006) identified the capital market as the most credible source of long-term funds to any economy and a leading economic indicator in developed economies. The stock market makes the interaction of both savers and investors possible in a country (in an open market), all the aggregate savings are channeled into most desirable investment for the purpose of economic growth and development.

A viable equity market can serve to make the financial system more competitive and efficient. Without equity markets, companies have to rely on internal finance through retained earnings. Large and well established enterprises are in a privileged position because they can make investment from retained earnings and bank borrowings, while new companies do not have easy access to finance. Without being subjected to the scrutiny of the stock market, big firms get bigger and for the emerging smaller companies, retained earnings and fresh cash injections from the controlling shareholders may not be able to keep pace with the needs for more equity financing which only an organized market place could provide (Popoola, 2014).

The Nigerian Capital Market came into being in 1960 as the Lagos Stock Exchange and was changed to the Nigerian Stock Exchange in December 1977. It began operations in 1961 with 19 securities listed for trading. Branches were opened in key cities of the country. There are 13 branches of The Nigerian Stock Exchange (excluding the head office in Lagos). The NSE was growing consistently in order to meet the needs of its customers and to achieve the highest level of competitiveness. The Exchange operates fair, orderly and transparent markets that bring together the best of African enterprises and the local and global investor communities. The Nigerian Stock Exchange is poised to champion the acceleration of Africa's economic development and to become "the Gateway to African Markets" Wikipedia (2012).

There has been a growing concern on the impact of stock market on economic growth. Stock market is often said to 
be the barometer of business direction, because of the benefit it provides to the firms and the economy at large, this made it to be a focus for the economists and policy makers. The development of capital market and apparently stock market enables government to mobilize long term capital for economic development, provide relevant information for appraisal (Inanga and Emenuga 1997).The role of stock market development has assumed a developmental role in global economies based on the impact the market exerted on the economic activity. Financial sectors pull funds from dispersed households and allocate them efficiently to dispersed entrepreneur and the tendency to spend money on "White Elephant" will be curtailed as only economically viable projects could be finance from capital market.

Stock market contributes to economic growth through the specific services it performs either directly or indirectly. Notable among the functions of the market are mobilization of savings, creation of liquidity, risk diversification, improve dissemination, acquisition of information, and enhance incentives for corporate controls. Improving the efficiency and effectiveness of these functions through prompt delivery of the services can increase the rate of economic growth (Oloyede, 2001; Ohiomu et al, 2011, p 288). Bekaert and Harvey (1997) outlined that an efficient capital market would mean for an economy and a country at large.

The broad objective of this study is to examine the impact of stock market on economic growth in Nigeria and the study thus seeks specifically to examine the trend in Nigeria's stock market and analyze the direction of casualty between stock market parameters (in terms of size, actual performance and the inclusion of the gross capital formation among the gaps found in literature) and economic growth in Nigeria. Studying the relationship between Stock market and real output growth is important because of the need to understand the complex link between the two variables. A strong capital formation will also ensure the citizens are enlightened on the benefit of stock market through media. This will solve the problem of awareness of stock exchange. This is further structured as follows: section two consists of the literature review which shows the insights from relevant literature. The next section (three) is the theoretical framework and methodology which is then followed by section four (results and discussion) and finally the summary, conclusion and recommendation as the section five.

\section{LITERATURE REVIEW}

Kuznets (1971) defines a country's economic growth as a long - term rise in the capacity of supply leading to increase in the production of goods for the population accompanied by advancing technology and the institutional and ideological adjustment that it demands. It therefore encompasses growth, structural and institutional changes and the essential elements that make up life such as education, health, nutrition and a better environment i.e. human and development indices.

Ekundayo (2002) argues that a nation requires a lot of foreign investment to attain sustainable economic growth and development, the capital market provides means through which that is made possible. Several policies and programs have been consciously created to promote the growth of the Nigerian economy overtime. Some of these policies include the enterprises promotion decree, the privatization of government enterprises (2000), which were quoted on the Nigerian stock exchange. There were also the bank recapitalization directives (2004), by the CBN, in which banks were directed to recapitalize to a minimum of twenty five billion naira. For this many banks accessed the capital market (through the primary public offers) for their financing needs, the government also introduced the pension reform Act of 2004. This act provides that part of the pension fund should be invested in the capital market by pension fund administrators.

However, the impact of the capital market on the growth and development of the economy has not been significantly positively felt (Babalola, 2007). This may be due to low market capitalization, delay in delivery of share certificate problem of manual call, slow growth of securities market, double taxation, problem of macro-economic instability among others. Also, most Nigerians are not aware of the benefit derivable from the market operations. Furthermore, there is a problem of reluctance of Nigerian businessmen to go to the public for fear of losing control of their business. More so, the Nigerian stock exchange market, over the years has undergone reforms due to the declining effect of global financial crisis. While capital market has the potentials of stimulating economic growth and development through effective resource allocation, the expected high economic growth that comes with capital market development has not been experienced in Nigeria (Popoola, 2014).

A long run relationship between the growth of GDP and capital market efficiency in Nigeria using time series data showed that though the Nigerian capital market has the potential to induce growth, there has not been any meaningful contribution to the economic growth of Nigeria. 
This was attributed to low market capitalization, low absorptive capitalization, illiquidity, misappropriation of funds and so on (Ewah, Esang \& Bassey 2009; Okpara, 2010)

Ezeoha, Ebele. \& Onyinke (2009) investigated the nature of the relationship that exists between stock market development and the level of investment - domestic private investment and foreign private flows into Nigeria. The authors discovered that stock market development promotes domestic private Investment flows, thus suggesting the enhancement of the economy's production capacity as well as promotion of the growth of national output. However, the results show that stock development has not been able to encourage the flow of foreign private investment in Nigeria. However, gross capital formation was omitted in the model specification.

Osinubi and Amaghionyeodiwe (2003) also examined the relationship between Nigeria stock market and economic growth during the period $1980-2000$ using ordinary least squares regression (OLS). The result showed that there is a positive relationship between the stock market development and economic growth and suggest the pursuit of policies geared towards rapid development of the stock market.

Nurudeen (2009) carried out a research on whether stock market development raises economic growth in Nigeria, by employing the error correction approach and the results indicated that stock market development (market capitalization to GDP ratio) increased economic growth in Nigeria. The study also made recommendations such as the removal of impediments to stock market development which include tax, legal, and regulatory barriers; and the employment of policies that would increase the efficiency of firms as well as encourage the access of capital on the stock market and also enhance the capacity of the Nigerian Security and Exchange Commission so as to facilitate the growth of the stock market, restore the confidence of stock market participants and safeguard the interest of shareholders by checking sharp practices of market operators (particularly spectators).

Ishioro (2013) Investigated the causal linkage existing between stock market development and economic growth in Zimbabwe for the period 1990:I to 2010:IV, applying the ADF unit root test and the long-run Granger non-causality estimation technique. The proxy used for the stock market was the real market capitalization and the real GDP growth rate to represent economic growth. The results showed that a bi-directional causality exists between economic growth and stock market development in Zimbabwe.

Study of the GSE (Ghana Stock Exchange) carried out by Osei (2005) interestingly revealed that stock market performance granger - causes economic growth in Ghana economy. Quite interestingly, the study did not find a reverse causality, but rather a unidirectional relationship. This upheld the fact that economic growth does not predict stock market development in Ghana. However, the researchers attributed this unidirectional causality to the low level of incomes as evidenced in most developing economies.

Odhiambo (2010) examined the causal relationship between stock market development and economic growth in South Africa. The study used annual time series data for the period $1971-2007$ and the autoregressive distributed lag (ARDL) - Bounds testing method was employed. Three constituents of stock market performance, namely stock market capitalization, stock market traded value and stock market turnover were used against real GDP per capita, a constituent for economic activity. Empirical results showed that the causal relationship between stock market performance and economy activity is susceptible to the components used for measuring stock market development. When market capitalization was used as a measure of stock market performance, economic growth was seen to Granger - cause stock market development. Moreover, when stock market turnover was used, stock market development seemed to Granger - cause economic growth. The results were valid both in the short and long run.

Enisan \& Olufisayo (2009) investigated the long run and causal relationship between stock market performance and economic growth from seven countries in Sub - Saharan Africa using the autoregressive distributed lag (ARDL) test. Stock market capitalization was used as proxy to stock market development while GDP was used as an economic activity proxy. The Co - integration test result revealed that stock market development and economic growth were cointegrated in Egypt and South Africa. Results showed that stock market development has a positive and significant long run relationship with economic activity. Causality tests using the Granger tests on vector error correction model (VECM) showed that stock market performance Granger cause economic activity in Egypt and South Africa. Granger causality in the context of VAR showed evidence of bi directional causality between stock market performance and economic growth for Cote D' Ivoire, Kenya, Morocco, and Zimbabwe. Based on results, the study argues that stock markets can help promote the growth of Africa.

Mishra (2010) examined the impact of capital market efficiency on economic growth in India using the time series data on market capitalization, total market turnover and stock price over the period spanning from first quarter of 1991 to first quarter of 2010. Their study revealed that 
there is a linkage between capital market efficiency and economic growth in India. This linkage is through high rate of market capitalization and total market turnover. A larger size of the capital market (market capitalization) is positively related with the ability to mobilize and diversify risk on an economy wide basis. The increasing trends of market capitalization in India would certainly bring about efficiency in capital market and thereby contribute to economic growth.

Oskooe (2010) assessed the relationship between stock market performance and economic growth in Iran by using causality tests within a Vector Error Correction Model (VECM) structure. Quarterly time series data was used from the third quarter of 1997 to the third quarter of 2008. As a precaution to prevent spurious regression, unit root tests were done for all time series data in their levels and their first differences. Johansen's co - integration testing was used to examine whether the variables are co-integrated, taking into account the maximum Eigen values and trace statistics tests. Ultimately, the Granger causality test was used to identify direction of causality between the variables of the estimated model. It was observed that the level of real economic activity was the key feature in the movement of stock prices in the long run. Furthermore, the stock market plays a role as a leading business cycle indicator of future economic growth in Iran in the short run. The results from this study are realistic because, when the stock market performs well, the impact is transferred to businesses and this in turn impacts on the overall economic growth.

Pan and Mishra (2016), investigated stock market development and economic growth in China (the largest and fastest growing economy in the world) using the ARDL method and discovered that the global financial crises had a significant impact on both China's real sector and financial sector. The results also showed that the share market has a long run negative association with the real sector of the economy. However, the magnitude of the impact is tiny and can be ignored. It was also found with the Toda Yamamoto's causality test that there is evidence of a demand driven hypothesis that economic growth spurs stock market development in China. However, there was no theoretical framework in the study to back up the work.

\section{THEORETICAL FRAMEWORK AND METHODOLOGY}

\subsection{Theoretical Framework}

In this study we consider the application of the financial market theory of development and efficient market hypothesis (EMH) given that stock market provides capital to boost economic growth which may vary according to the level of development of an economy as proposed by theories.

The use of private flows of capital and stock market creation began to shape into a new theory of development put forward by the World Bank Development Report (2000). The theory impliedly posits that investors (foreign or domestic) should have access to 'well regulated' financial markets which would provide the 'surest path' to economic growth and development. Business in low income countries gain direct access to the private capital from industrialized countries. The benefits of investors are rooted in prospective growth rates which are unattainable in advanced economics and high returns matching the risks involved. This is known as the 'financial market theory of development'. An assumption that accompanies this theory implies that stock markets will improve economic growth to the degree based on how integrated they are into an 'institutional matrix' that sends signals to decision makers who would look for growth opportunities (Weber, Davis and Lounsbury, 1980; Wikipedia, 2014). Economic growth is boosted due to reduction in the riskiness of investment facilitated by stock market liquidity. Levine (1991) came up with a theoretical model which states that stock market can improve capital accumulation and growth by reducing liquidity cost, increasing average productivity of capital and rate of savings.

The theoretical explanation on the nexus between capital market and economic growth is further expanded using Efficient Market Hypothesis (EMH) developed by Fama in 1965. According to EMH, financial markets are efficient on prices of traded assets that reflect all known information and therefore are unbiased because they represent the collective beliefs of all investors about future prospects. Previous test of the EMH have relied on long range dependence, because of the narrowness of their market arising from immature regulatory and institutional arrangement (Nagayasu, 2007 and Nyong, 2003). Note that, where the market is highly and unreasonably speculative, investors will be discouraged from parting with their funds for fear of incurring financial losses (Edame \& Okoro, 2013). Situations like the one mentioned above, has detrimental effect on economic growth of any country which implies that investors will refuse to invest in financial assets. They also observed that a positive and significant relationship exists between GDP growth turnover ratios. The authors advised that government should encourage the development of the capital market since it has a positive effect on economic growth. 


\subsection{Methodology}

This study adopts an empirical model from Abu (2009); Adenuga (2010); Omoruri \& Osaretin (2015). Expressing the model implicitly:

$$
Y_{t}=A f(G C F, M C A P, A S I, V T R)
$$

Where; Real Gross Domestic Product (Y): This is the monetary value of aggregate economic activities within a period of time. It is an index of economic growth in a country, it could also be used to measure economic performance in an economy.

Gross Capital Formation (GCF): Economic theories suggest that capital will be more in a country where there is abundance compare to a country where there is scarcity. GCF can be use to represent capita; inputs.

Market Capitalization (MCP): This is the total market value of the issued share capital of all the companies quoted on the stock exchange. Capitalization also refers to the act of converting net retained profit or reserve into issued capital.

All Share Index (ASI): Statistical data computed annually for the period of 1980 to 2014 to measure the changes in the value of commodities and securities. The index is derived from the price of all or some market constituents, usually expressed in percentage change from base period. Indices are important performance of an economy or a financial market.

Value of transaction (VTR): This is the total value of transactions traded on the stock market exchange divided by the GDP. It measures the organized trading of firm equity as a share of national output and therefore should positively reflect liquidity on an economic wide basis. The total value of transaction complements the market capitalization ratio.

Expressing the model explicitly:

$Y_{t}=A G C F_{t}^{\alpha 1} M C A P_{t}^{\alpha 3} \mathrm{e}^{\alpha 4 A S I+\alpha 5 V T R}$

Expressing in log-linear form,

$\ln Y_{t}=\alpha_{0}+\alpha_{1} \ln G C F_{t}+\alpha_{3} \ln M C A P_{t}+\alpha_{4} A S I+\alpha_{5} V T R$

This paper employs the Ordinary Least Squares (OLS) to check for the short run impact; Johansen co-integration test to check for long-run relationship between dependent and independent variables and the Error correction mechanism (ECM) is used to know the short run dynamics between dependent and independent variables.

Unit root test for stationarity were conducted for the variables. This is a very crucial step given that, in the literature most time series variables are non-stationary and using non-stationary time series on another non-stationary time series in the model might lead to spurious estimation and estimates (Granger, 1996). The first and second different terms of most variables will usually be stationary if it has constant mean value equilibrium, where there is disequilibrium, as well as zero order of integration $\mathrm{I}(0)$. The $\mathrm{ADF}$ is conducted by adding the lagged values of the dependent variables with the independent variables in regression. The most famous test is the one specified above and another test is the Phillips Peron test. Both use the existence of a unit root as the null hypothesis. The null hypothesis of non-stationarity is tested using the t-statistic with critical values calculated by Mackinnon (1996). The null hypothesis that the series is $\mathrm{I}(0)$ is rejected when the test statistics is more negative than the critical value and is significant in favor of the alternative hypothesis that the series is stationary.

The theory of multivariate co-integration, as propounded by Johansen and Joselius provides a nexus or connection among integrated process and the notion of long-run equilibrium. The concept of co-integration explains that although two different series may not themselves be stationary, some linear combination of the two may indeed be stationary with the generalization of more than two series. (Komolafe, 1996). The general rule is that variables of different order cannot co-integrate otherwise the linear combination will not be stationary.

The original co-integration model can be specified as follows;

$\ln Y_{t}=\alpha_{0}+\alpha_{1} \ln G C F_{t}+\alpha_{3} \ln M C A P_{t}+\alpha_{4} A S I+\alpha_{5} V T R$

Where Y represent endogenous variable, which is output level in the Nigeria economy. "GCF, MCAP, ASI, VTR" are the exogenous variables earlier specified.

The co-integration test commenced with a test for the number of co-integrating relation or rank (r) of $\pi$ using Johansen's Maximal Eigen value of stochastic matrix and the likelihood Ratio (LR) test based on the trace of the stochastic matrix $\pi$ which is the long-run multiplier matrix $\mathrm{m} * \mathrm{n}$ that is the coefficients. Note that the Eigen value of $\pi_{1}$ are the roots of the $k^{\text {th }}$ order characteristics polynomial $\left(\pi_{1}-v_{1}\right)$ obtained by solving the characteristics equation.

Also, the trace statistics suggested by Johansen to determine the co-integration rank in a multivariate model is based on the ordered (estimate) Eigen value. This test allows for the comparison of co-integration rank of ' $r$ ' against the alternative of co-integrating rank of $r+1$. This test may then be repeated for larger values of ' $r$ ' until one fails to reject the null hypothesis. The Johansen representation theorem establishes the theoretical basis of error correction modeling formally. According to the theorem, if $\mathrm{y}$ and $\mathrm{x}$ are cointegrated, then there is a long-run relationship between them.

The short-run adjustment dynamics can be usefully described by the error correction model (ECM). The ECM 
coefficient shows how quickly variables return to equilibrium and it should have a statistically significant coefficient. The Error correction techniques correct for disequilibrium between short and long run behavior of the dependent variable. Since disequilibrium may exist in the short-run, there is need to tie the value of the dependent variable to its long-run value. The error term from the cointegrating/ initial regression is called "equilibrium error". In simple term, the ECM involves using lagged residual to correct for deviations of actual values from long-run equilibrium values.
In applied work we require that the coefficient of ECM be significant (between zero and one) and negative. The sign should be negative if it plays the role of error correction. Specifically, if actual equilibrium value is too high, the error correction term will reduce it while if it is too low, the error correction term will raise it, Dickey Fuller (1981). The ECM according to Henry and Richard (1983) is very appealing due to its ability to induce flexibility, by combining both the short-run and long-run dynamics in a unified system. A Granger causality test would also be performed to test for the direction of causality between the independent and dependent variables.

IV. RESULTS AND DISCUSSIONS

Table.4.1: Dependent variable: LOG RGPD; Mode1: OLS observations 1980-2014 (T=35)

\begin{tabular}{lcccl}
\hline & Coefficient & Std. Error & t-ratio & p-value \\
\hline Const & 11.8086 & 0.299586 & 39.4163 & $0.00001 * * *$ \\
LOG(GCF) & 0.04510 & 0.421116 & 1.0710 & 0.29576 \\
LOG(MCAP) & 0.25542 & 0.031640 & 8.0727 & $0.00001 * * *$ \\
LOG(ASI) & -0.1560 & 0.065122 & -2.3963 & $0.02550^{* *}$ \\
LOG(VTR) & 0.02199 & 0.010137 & 2.1697 & $0.04110^{* *}$
\end{tabular}

R-squared $=0.963603, \mathrm{~F}(4,33)=145.6122(0.0000)$

The OLS results in table 4.1 show that gross capital formation $(\mathrm{GCF})$ is statistically insignificant at 5 percent level but has a positive impact on the gross domestic product (RGDP). Furthermore, a unit increase in GCF will lead to about 0.045 increase in economic growth (RGDP). Market capitalization (MCAP) shows a positive and significant relationship with RGDP and furthermore, a unit increase in MCAP will bring about 0.26 increase in RGDP, this is an evidence of positive capacity of the stock market as alternative sources of financing development and growth other than banks, implying increasing capacity of the market to mobilize savings, improve investment and accelerate economic development. The value of transaction in the stock market (VTR) has a positive and significant impact on output growth in Nigeria, a unit increase in VTR will lead to 0.022 increase in RGDP. In addition, The All Share Index (ASI) has a negative and significant impact on the performance of the Nigeria economy. A unit increase in ASI will lead to about 0.156 decrease in RGDP.

The coefficient of determination $\left(\mathrm{R}^{2}\right)$ shows that about 96.3 percent of the total variation in real gross domestic product (RGDP) is explained by the independent variables in the model. The adjusted $\left(\mathrm{R}^{2}\right)$ which penalizes the unnecessary variables also indicate that about 95.6 percent of the total variation in RGDP is explained in the model. From the OLS regression result (table 4.1 above), at 1 percent statistical significance level, the calculated F statistics (145.6122) is greater than the tabulated. Hence the overall regression is statistically significant at 5 percent level of significance. The Durbin Watson statistics fall within the positive autocorrelaton region i.e $0<\mathrm{d}<\mathrm{d}$ l where $\mathrm{d}=$ Durbin Watson $=0.756$ and $\mathrm{dl}$ is lower Durbin Watson=1.034. hence there is presence is autocorrelation.

Caution has to be taken before believing the worthiness of our regression result. This is because $\mathrm{R}$ squared shows that there is possibility of spurious regression. Also, the fact that there is presence of autocorrelation shown by the DurbinWatson result, the OLS assumption of "absence of autocorrelation" in the time series is violated. Therefore, the result from the OLS is suspicious. Hence, a test of stationary (unit root test) will be conducted as a requirement for the contegration test; the Augmented Dickey Fuller (ADF) unit root test. The results are shown below:

Table.4.2: Result of the Augmented Dickey Fuller Unit Root Test

\begin{tabular}{|c|c|c|c|c|c|c|}
\hline \multirow[t]{2}{*}{ Variables } & \multicolumn{2}{|c|}{ ADF test stat } & \multicolumn{2}{|c|}{ Critical Value } & \multirow[t]{2}{*}{ Interpretation } & \multirow[t]{2}{*}{ Remarks } \\
\hline & Level & $1^{\text {st }}$ Diff & $1 \%$ & $5 \%$ & & \\
\hline LOG(RGDP) & -4.6693 & - & -3.6702 & -2.9639 & $\mathrm{I}(0)$ & Stationary \\
\hline LOG(GCF) & -1.2156 & -2.9739 & -3.6702 & -2.9639 & $\mathrm{I}(1)$ & Stationary \\
\hline
\end{tabular}




\begin{tabular}{lllllll}
\hline LOG(MCAP) & 0.5707 & -4.2446 & -3.6702 & -2.9639 & $\mathrm{I}(1)$ & Stationary \\
LOG(ASI) & -1.3813 & -5.4579 & -3.6702 & -2.9639 & $\mathrm{I}(1)$ & Stationary \\
LOG(VTR) & -1.5647 & -5.4322 & -3.6702 & -2.9639 & $\mathrm{I}(1)$ & Stationary \\
\hline
\end{tabular}

Source: (Authors' computation, 2017)

The result shows that almost all the variables were nonstationary at their levels because there absolute ADF values are less than the critical value. Consequently, all variables were subject to first differencing so as to ensure stationarity and the result shows that all the variables attained stationarity at $1^{\text {st }}$ differencing, except RGDP that attained stationarity at level. The hypothesis of non-stationarity was rejected for the entire variables; this means that any shock or disturbance in them will be sustained for a short period. Since stationarity is attained for all the variables, we can now proceed to co-integration test.

Table4.3: Co-integration Rank Test Result

\begin{tabular}{cllllll}
\hline$H_{0}$ & $H_{1}$ & Eigen value & $\lambda \max$ test & $\lambda \max (0.95)$ & Trace test & Trace $(0.95)$ \\
\hline$r=0$ & $r=1$ & 0.904256 & $68.03631^{* *}$ & 33.87687 & $133.3223^{* *}$ & 69.81889 \\
$r \leq 1$ & $r=2$ & 0.642201 & $29.80571^{* *}$ & 27.58434 & $65.28601 * *$ & 47.85613 \\
$r \leq 2$ & $r=3$ & 0.518049 & $21.16749 * *$ & 21.13162 & $35.48030^{* *}$ & 29.79707 \\
$r \leq 3$ & $r=4$ & 0.332908 & 11.74000 & 14.26460 & 14.31281 & 15.49471 \\
$r \leq 4$ & $r=5$ & 0.084896 & 2.572810 & 3.841466 & 2.572810 & 3.841466 \\
\hline
\end{tabular}

Note: $(* *)$ denotes rejection of hypothesis at $5 \%$ level of significance.

Max-eigen value test indicates 3 co-integrating equations at $5 \%$ level

The co-integration results (table 4.3) based on the trace test request the null hypothesis of no co-integration among variables to be rejected. The rejection of the null hypothesis is as a result of the fact that there are at most three cointegrating equations among the variables at 5\% level of statistical significance. Similarly, the co-integration test result based on the maximal eigen value also confirmed that there are three co-integrating equations at 5\% level of significance. Given that there is existence of co-integration among the variables, it is important to state that there might be disequilibrium in the short-run. To correct for this possible disequilibrium, the error correction mechanism model (ECM) is employed and the results are stated below in table 4.4:

Table.4.4: Short-Run Model- ECM Result

\begin{tabular}{lllll}
\hline Variables & Coefficient & Std. Error & t-statistics & P-value \\
\hline LOG(GCF) & 0.00222 & 0.01912 & -0.1160 & 0.9088 \\
LOG(MCAP) & -0.00121 & 0.06739 & 0.01790 & 0.9859 \\
LOG(ASI) & -0.00503 & 0.06988 & -0.07193 & 0.9433 \\
LOG(VTR) & 0.00416 & 0.00842 & 0.4940 & 0.6264 \\
ECM(-1) & -0.620854 & 0.148965 & -4.168 & 0.0004 \\
\hline
\end{tabular}

$\begin{array}{lccc}\text { Mean dependent var } & 0.055840 & \text { S.D. dependent var } & 0.04 \\ \text { Sum squared resid } & 0.050279 & \text { S.E. of regression } & 0.048931 \\ \text { R-squared } & 0.510301 & \text { Adjusted R-squared } & -0.17 \\ \text { F }(4,21) & 0.080509 & \text { P-value(F) } & 0.987484 \\ \text { Log-likelihood } & 44.33492 & \text { Akaike criterion } & -78.66983 \\ \text { Schwarz criterion } & -72.37935 & \text { Hannan-Quinn } & -76.85840 \\ \text { Rho } & 0.352879 & \text { Durbin-Watson } & 1.665879\end{array}$

Having established the stationarity and the long-run relationship in the previous results, we can therefore restate our model as follows;

$$
\begin{gathered}
\ln D(R G D P)=\beta_{0}+\beta_{1} \ln D(G C F)+\beta_{2} \ln D(M C A P)+\beta_{3} \ln D(A S I)+\beta_{4} \ln D(V T R)+\beta_{5}(E C M)_{t-1}+\varepsilon_{t} \\
\ln D(R G D P)=0.00222(G C F)-0.00121(M C A P)-0.00503(A S I)+0.00416(V T R)-0.62085(E C M)_{t-1}+\varepsilon_{t}
\end{gathered}
$$

Where; $\mathrm{D}=$ difference parameter; $(E C M)_{t-1}=$ one period lagged value of the error from the initial regression. 
From the result, ECM is negative (-0.62) which is also significant at 1 percent level. The speed of adjustment to equilibrium in its current period is about 62 percent This implies that about 62 percent of the disequilibrium in the RGDP is offset by the short-run adjustment in each period. With respect to the ECM, (since stationarity has been built in our model) it is obvious that the value of the durbin watson has changed drastically. The ECM shows a durbin watson value of 1.66. This value falls between $\mathrm{Du}<\mathrm{d}<4$ $\mathrm{du}$. Therefore it is deduced that there is no autocorrelation. This means that our estimates could be used for policy forecast and predictions because our parameters estimates from our model are stable.

Table.4.5: Result of Granger Causality Test

\begin{tabular}{lllll}
\hline Direction of Causality & F-Stat & Prob & Accept/Reject $\mathrm{H}_{0}$ & Lags \\
\hline $\mathrm{GCF} \rightarrow$ RGDP & 6.11730 & 0.0200 & Reject & 1 \\
$\mathrm{MCAP} \rightarrow$ GCF & 0.88230 & 0.3559 & Accept & 1 \\
$\mathrm{MCAP} \rightarrow$ RGDP & 1.39810 & 0.2474 & Accept & 1 \\
$\mathrm{RGDP} \rightarrow$ MCAP & 10.7893 & 0.0028 & Reject & 1 \\
$\mathrm{ASI} \rightarrow$ RGDP & 2.48490 & 0.1266 & & \\
$\mathrm{RGDP} \rightarrow$ ASI & 6.17841 & 0.0194 & Accept & 1 \\
$\mathrm{VTR} \rightarrow$ RGDP & 0.67857 & 0.4173 & Reject & 1 \\
RGDP $\rightarrow$ ASI & 1.14990 & 0.2931 & Accept & 1 \\
& & & Accept & 1 \\
\hline
\end{tabular}

In the table 4.5 above, a strong unidirectional causality running from gross capital formation (GCF) to real gross domestic product (RGDP) at 5 percent level of significance exist. Also, a unidirectional relationship was found between real gross domestic product and market capitalization with causality running from real gross domestic product (RGDP) to market capitalization (MCAP) at 5 percent level of statistical significance. Market capitalization (MCAP) from the result, does not granger cause real gross domestic product (RGDP), this could be as a result of the fact that the impact of capital market has not been significantly felt (Babalola, 2007) due to factors like low market capitalization, slow growth on the security market and macro-economic instability. There is also a unidirectional relationship existing from real gross domestic product (RGDP) to all share index (ASI). Finally, it can be observed from the test that there is no causality between real gross domestic product (RGDP) and the value of transaction (VTR).

\section{SUMMARY, CONCLUSION AND RECOMMENDATION}

Some researchers with focus on the stock market did not only develop new theories on capital markets but also refined existing ones which are considered sophisticated and efficient in the interpretation of relevant information. Insights from literature showed that the relationship existing between economic growth and the stock market has not been examined from the whole view of including the variables that show the size and performance of the stock market with the inclusion of gross capital formation of the economy in the model for the selected time period based on data availability (1980 - 2014). The performance of Nigerian stock market was assessed through the utilisation of social scientific methodology to gross capital formation, market capitalization, all share index, value of transaction of issues and real gross domestic product.

The study, from the OLS result confirms that there exist a positive and significant relationship between market capitalisation and economic growth; value total ratio and economic growth while a significant but negative relationship exist between the all share index and economic growth. This means that a unit increases in the size of stock market and the liquidity of the market has significant impact in measuring the economic growth and development in Nigeria. The negative relationship between stock market all share index and economic growth could be explained by the weak regulatory institutions and higher degree of price volatility on stock markets which reduce the efficiency of price signals in allocating investment resources.

The formal test for stationarity applied is the Augmented Dickey Fuller unit root test. All the time series data were found to be stationary at order one (1), except for Economic growth (RGDP) that was stationary at level. The cointegration test provided that there is a long-run relationship between stock market size and performance variables and economic growth. The empirical results of the granger causality test, conducted in this study support the view of 
presence of a causal link between stock market performance and economic growth. The study argues that there exist an un-directional causality between stock market performance and economic growth in Nigeria. Specifically, economic growth granger causes market capitalization and no feedback mechanism was confirmed; economic growth granger causes all share index in Nigeria and all share index does not granger cause economic growth in Nigeria. Also, the result confirms that there is no directional causation between economic growth and gross capital formation in Nigeria; economic growth and value of transaction in Nigeria.

Based on the findings from this study, the following recommendations are suggested. The demand for the services of the stock market is a derived demand; there should be sustained effort to stimulate productivity in both the public and private sectors. The government through its respective specialty units should boost savings and investors' confidence by putting in place policies which give equal importance to both bank-based financial sector as well as the market-based stock economy in order to enhance capital formation; encourage private sector to invest in capital market. This can be done through educating and enlightening the public using experts that are competent in stock market dealings. There should be improvement in the dealing process in the market capitalization to encourage foreign investors to participate in the market. Also, government should discourage Nigerian investors' attitude of buy and hold securities instead of trading in the capital market. Communication and information network should be upgraded

\section{ACKNOWLEDGEMENTS}

This paper draws from the second author's undergraduate research project at Landmark University. Thus, suggestions and comments from research committee and faculty in the Department are acknowledged. In addition, the authors appreciate support from Covenant University Centre for Research, Innovation and Development (CUCRID)

\section{REFERENCES}

[1] Abu .N. (2009). Does stock market development raise economic growth? Evidence from Nigeria. Journal of Banking and Finance. 1(1), 15-26

[2] Adenuga, A.O. (2010). Stock market development indicators and economic growth in Nigeria: EmpiricalInvestigation, Central Bank of Nigeria Economic and Financial Review. 48(1), 21 32.
[3] Ahmed, Salik M. (1998). Capital Market. Business Times.

[4] Babalola, S. (2007). Benefits of Capital Market to indigenous enterprises in Nigeria. Security market journal, special edition. 9, 86.

[5] Baldwin, R. (1991). On the microeconomies of the European Monetary Union.

[6] Bekaert, G., and Harvey, C.R. (1997). Capital Markets An Engine for Economic Growth.

[7] Edame, G. E. and Okoro, U. (2013). An Analysis of the Nigerian Capital Market Performance and Economic Growth in Nigeria. Journal of Poverty, Investment and Development. Retrieved from:

[8] http://www.iiste.org/Journals/index.php/JPID/article/vi ewFile/9254/9467

[9] Ekundayo, K. (2002). Creating Conducive Environment for Investment in Nigeria Capital Market. Paper Presented at Public Enlightenment on opportunities in the Capital Market for Industrial Development of Kogi State. Lokoja 29 ${ }^{\text {th }}$ March to $1^{\text {st April, } 2002 .}$

[10] Eagle, R.F., \& Granger, C.W.J. (1987). Co-integration and error correction: presentation, estimation and testing. Econometrica, 55, 1-87.

[11] Enisan, A.,\& Olufisayo, A.O.(2009). Stock Market Development and Economic Growth: Evidence from seven Sub-Sahara African Countries". Journal of Economics and business, 61(2).

[12] Ewah, S., Esang, A., \& Bassey, J. (2009), Appraisal of Capital Market Efficiency on Economic Growth in Nigeria. International Journal of Business and Management. 4(12). www.cesenet.org/journal.html. Retrieved $23^{\text {rd }}$ September, 2012.

[13] Ezeoha, A., Ebele, O., \& Ndi Okereke, O. (2009). Stock Market Development and Private Investment Growth in Nigeria". Journal of Sustainable Development in Africa, 11(2).

[14]Fama, E.F. (1965), The Behaviour of Stock Market Prices, Journal of Business 39(1) 31-65.

[15] Granger, C.J. (1981), Some Properties of Time Series Data and their Use in Econometric Model Specification. Journal of Econometrics. 16. 121-30.

[16] Granger, C.J. (1986), Developments in the Study of Co-integrated Economic Variables. Oxford Bullletin of Economics and Statistics, 48(93), 213-28.

[17]Inanga, J. L., \& Emenuga C. (1997), Institutional, Traditional and Asset Pricing Characteristics of the Nigerian Stock Exchange. African Economic Research Consortium Research paper. 
[18] Ishioro O. B. (2013), Stock Market Development and Economic Growth: Evidence from Zimbabwe. EKON. MISAO PRAKSA DBK

[19] Mishra, P.K., U.S., Mishra, U.S., Mishra, B.R., \& Mishra. P. (2010). Capital Market Efficiency and Economic Growth. The Case of India. European Journal of Economics, Finance and Administrative Sciences Issue 27 (18).130-138.

[20] Nagayasu, J. (2003). The Efficiency of the Japanese Equity Market. IMF Working Paper No. 142.

[21] Nurudeen, A. (2009). Does Stock Market Development Raise Economic Growth? Evidence from Nigeria. The Review of Finance and Banking, 1(1), 15-26. $\quad$ Retrieved from http;//www.rfb.ase.ro/articole/RFB5.pdf.

[22] Nyong, M.O.(1997). Capital Market Development and Long Run Economic Growth; Theory.

[23] Nyong,M.O. (2003). Predictability and Volatility of Stock Return in Three Emerging Markets: Nigeria, South Africa and Brazil. Nigeria Journal of Economics and Development Matters 2(1): 12-29.

[24] Odhiambo, N.M. (2010). Stock market development and economic growth in South Africa: An ARDIBounds. Department of Economics, University of South Africa.

[25] Okereke. O.W. (2006). Enhancing the growth of the capital market through Federal Government Initiative. Second animal national capital market conference.

[26] Okpara, G.C. (2010), Analysis of Capital Market Performance and the Growth of the Nigerian Economy: A Co-integration Approach. Global Journal of Human Social Science 10(1) September. http://globaljournals.org/GJHSS- Volume10/2Analysis- of-Capital Market- Performance-and-theGrowth-of-the-Nigerian-Economy.CointegrationApproach-Copy.pdf. Retrieved $23^{\text {rd }}$ September, 2012.

[27] Ohiomu, S. and Enabulu, O. G. (2011). The Effect of Stock Market on Economic Growth in Nigeria.

JORIND (9)1, ISSN 1596-8303. Retreived from: www.transcampus.org/journals. www.ajol.info/journals/jorind

[28] Oioyede, B. (2001).Fundamentals of investment analysis. Lagos: Lion press.

[29] Ole, M. O. (2013). Capital Market Operations and Economic Growth in Nigeria. International Journal of Business and Social Science. Retrieved from http://www.ijbssnet.com/journals/Vol_4_No_7_July_2 013/18.pdf
[30] Oppenlander, K.H. (1997). Business Cycle Indicators. England Antony Rowe Ltd

[31] Osei, V. (2005) Does the Stock Market in Ghana? A Granger Casuality Analysis Bank of Ghana Working Paper 05(13).

[32] Osinubi, T. S., \& Amaghionyeodiwe, L.A. (2003). Stock Market Development and Long-run Growth in Nigeria. Journal of African Business, 4(3), 103-129.

[33] Oskooe, S.A.P. (2010), Emerging Stock Market Performance and Economic Growth. School of Economics, Kingston University. American Journal of Applied Sciences 7(2): $\quad$ 265-269.

[34]Pan L. \& Mishra V. (2016), Stock Market Development and Economic Growth: Empirical Evidence from China. Department of Economics Discussion Paper 16/16, ISSN 1441- 5429, Monash Business School

[35] Popoola, O. (2014). The Effect of Stock Market on Nigerian Economy. Unpublished Manuscript, Department of Economics, Landmark University, Kwara State, Nigeria.

[36]R. Engle and C. Granger. (1987). Co-integrated and error correction: Representation, estimation and testing. Econometrica. 55.251-276.

[37] R.M. Solow, (1956). A contribution to the Theory of Economic Growth, Quarterly Journal of Economics. 70.65-94.

[38] Kuznets, S. (1971). Economic Growth of Nations: Total Output and Production, Structure, Harvard University Press, Cambridge, Mass, pp,10-27.

[39] Weber, K., Gerald, F. Davis, \& Michael Lounsbury., (1980-2005). Policy as Myth and Ceremony? The Global Spread of Stock Markets. Academy of Management Journal. 52(6):1319-1347.

[40]Wikipedia, (2014). Financial market theory of development-Wikipedia. Retrieved from: https://en.wikipedia.org/wiki/Financial_market_theory _of_development 